\title{
IDENTIFIKASI TECHNOLOGY DIGITAL DAN UANG DIGITAL DALAM BELANJA ONLINE PADA MASYARAKAT DI WILAYAH PERBATASAN KALIMANTAN BARAT
}

\author{
Yulia ${ }^{1}$ Hilda $^{2}$ \\ ${ }^{1}$ Universitas Bina Sarana Informatika \\ ${ }^{2}$ Fakultas Teknik Universitas Tanjungpura \\ Email korespondensi: yulia.yla@bsi.ac.id ${ }^{1}$
}

\begin{abstract}
Abstrak
Dalam memasuki era digitalisasi saat ini kita memanfaatkan berbagai bidang, tak terkecuali dalam bidang keuangan. Digitalisasi adalah bentuk macam media menjadi digital yang terjadi dari proses peralihan atau perubahan. Teknologi terus berkembang dengan pesat diikuti dengan perubahan zaman, sehingga mengharuskan masyarakat untuk membiasakan diri dan belajar serta mulai menerapkannya dalam aktifitas sehari-hari. Terjadinya disruptif dalam perkembangan teknologi tidak bertujuan menghilangkan tetapi lebih mengembangkan teknologi dengan mengkolaborasikan kebutuhan akan digitalisasi. Permasalahan yang dihadapi masyarakat adalah masih belum terbiasanya menggunakan uang digital dalam aktifitas keseharian terutama bagi masyarakat di wilayah perbatasan Kalimantan Barat. Tujuan dalam penelitian ini adalah untuk mengidentifikasi teknologi digital dan uang digital dalam belanja online, dengan menggunakan metode evaluasi deskriptif. Adapun hasil yang diharapkan adalah masyarakat di wilayah perbatasan Kalimantan Barat dapat terbiasa menggunakan teknologi digital berbasis uang digital dalam transaksi berbelanja. Pembayaran menggunakan uang digital dapat diterapkan di seluruh jenis transaksi pada berbagai sektor, seperti pembayaran masuk di pos wilayah perbatasan. Oleh karena itu, dengan opsi penggunaan metode pembayaran uang digital akan membantu menekan penyebaran virus COVID19.
\end{abstract}

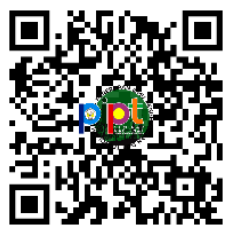

10.26418/pipt.2021.7

Kata kunci: identifikasi, teknologi digital, uang digital, belanja.

\section{PENDAHULUAN}

Perkembangan teknologi digital dari tahun ke tahun semakin pesat, ini dibuktikan dengan terus berinovasinya perusahaan elektronik guna penunjang kebutuhan digital (Peter \& Bican, 2020). Teknologi Digital adalah kegiatan komputer/digital dalam mengolah teknologi informasi yang dapat dibaca dengan sistem pengoperasian yang serba otomatis dan canggih dengan sistem komputerisasi/format (Danuri, 2019).

Penggunaan teknologi digital dapat membantu pekerjaan menjadi lebih efisiensi dan efektifitas, ini terbukti dengan munculnya start-up di era sekarang ini, seperti pemesanan tiket dan hotel yang telah melakukan kerjasama dengan start-up di bidang pariwisata seperti Mister Aladin dan Traveloka membuat transaksi yang semakin mudah dan efisien (Danuri, 2019). Masyarakat luas juga merasakan kemudahan dalam sistem pembayaran digital, seperti pembayaran di Tol, jasa ojek online, toko online dan beberapa jenis usaha yang menggunakan fasilitas pembayaran berbasis digital (Hendarsyah, 2016).

Pembayaran digital atau biasa juga disebut uang digital (elektronic money) cukup tinggi di daerah perkotaan, karena perputaran uang lebih cepat dibandingkan dengan di daerah-daerah pedesaan (Hendarsyah, 2016).

Kemunculan uang elektronik berdasarkan Peraturan Bank Indonesia Nomor 11/12/PBI/2009 dan Nomor 16/8/PBI/2014 yang dilatarbelakangi Bank Indonesia sebagai agenda untuk menciptakan masyarakat di Republik Indonesia ini dalam mengurangi penggunaan uang tunai (less cash society) (Bank Indonesia, 2018).

Ciri khas sistem pembayaran modern adalah bahwa uang digital (uang elektronik) digunakan untuk penyelesaian dan pembayaran, yang sebenarnya (Muralidhar, 
2019). Uang digital muncul membantu transaksi finansial masyarakat tanpa menggunakan uang tunai Larina and Akimov, 2020). Berkembangnya teknologi digital membuat bisnis startup sebut saja Shopee-Pay dari Shopee, Go-Pay dari GoJek, dan lainnya melakukan inovasi-inovasi dalam produk finansial digitalnya, (Hendarsyah, 2016).

Pada bulan Maret 2021, berdasarkan data jumlah pengguna e-wallet, ShopeePay merupakan e-wallet yang paling banyak digunakan (76\%), disusul oleh Gopay (57\%), Ovo (54\%), Dana (49\%), dan LinkAja (21\%) (Prasetyo, 2021).

Forum Ekonomi dunia yang diikuti oleh Indonesia ikut mempengaruhi kebijakan ekonomi di Indonesia, yaitu kebijakan tentang system pembayaran (Permana et al., 2019). Di Indonesia uang tunai sebagai alat pembayaran secara umum masih digunakan, padahal salah satu pemicu meningkatnya inflasi adalah banyaknya transaksi uang tunai yang beredar (Larina \& Akimov, 2020). Inilah yang membuat Jepang, Singapura, Inggris dan Amerika Serikat dan beberapa negara lainnya sudah terlebih dahulu menerapkan sistem pembayaran menggunakan uang elektronik (Hendarsyah, 2016; Tazkiyyaturrohmah, 2018; Muralidhar, 2019).

Wilayah perbatasan memiliki regulasi khusus dan dimensi, ini berimbas terhadap aktifitas keseharian masyarakat di wilayah tersebut. Apabila dilihat dari literasi digital, masyarakat masih menggunakan handphone sebagai media komunikasi cenderung hanya digunakan untuk mendukung komunikasi dua arah (menelpon), cenderung belum memanfaatkan teknologi lainnya seperti internet, kesiapan masyarakat dalam mendukung penerapan teknologi komunikasi akses internet masih terbilang rendah (Muazir dkk., 2020).

Kebutuhan harian masyarakat dapat ditemukan di pasar tradisional. Namun untuk saat ini ketika internet sudah menyentuh sampai ke pelosok daerah termasuk wilayah perbatasan (Latif \& Karmilia, 2017), membuat masyarakat juga dapat mengakses segala informasi dan kebutuhan melalui jaringan internet dengan teknologi digital (Latif \& Karmilia, 2017). Salah satunya adalah fasilitas belanja online yang disediakan oleh perusahaan-perusahaan start up, seperti Shopee, Lazada, Tokopedia, dan lain lain (Prasetyo, 2016). Penunjang untuk fasilitas belanja online salah satunya adalah web e-commerce (Hendarsyah, 2019).

Dalam transaksi pembayaran harian seperti di mini market atau supermarket, ketika kita belanja dan tidak ada uang kembaliannya kita akan diberikan permen, padahal hal tersebut belum tentu kita inginkan dan cenderung terpaksa. Dengan uang digital maka hal-hal seperti itu tidak akan terjadi lagi (Permana et al., 2019).

Perusahaan start up melengkapi system pembayaran secara digital, sehingga konsumen merasakan kemudahan dalam transaksi berbelanja online (Peter \& Bican, 2020). Penggunaan uang digital memiliki karakteristik yang berbeda dengan jenis kartu kredit atau kartu debit yang lebih dulu digunakan sebagai alat pembayaran yang inovatif dan praktis. Uang digital juga menjadi alternative yang dapat menjangkau masyarakat yang selama ini yang belum memiliki akses pada perbankan dalam melakukan pembayaran non-tunai (Inayah, 2020). Seperti pembayaran Shopee dapat dilakukan pada indomaret atau alfamart.

\section{METODOLOGI}

Penelitian ini menggunakan metode evaluasi deskriptif, adalah penelitian yang sistematis untuk mengetahui efektifitas suatu data/informasi, tindakan atau kebijakan atau obyek lain yang diteliti jika dibandingkan dengan standar yang telah ditetapkan. Penelitian evaluasi dilakukan berdasarkan umpan balik dari orang-orang yang terlibat dalam pelaksanaan program tersebut dengan tujuan untuk meningkatkan efektivitas suatu kebijakan atau program (Sugiyono, 2013).

\section{HASIL DAN PEMBAHASAN}

Perkembangan sistem pembayaran digital di Indonesia dimulai pada tahun 2009 
(Permana dkk., 2019), nilai transaksi keuangan mengalami peningkatan setiap tahunnya. Indonesia merupakan salah satu pendorong utama pertumbuhan uang digital di Asia Tenggara, Malaysia, Singapura, Filipina, dan Thailand (Aimon et al., 2021).

Pada wilayah perbatasan diketahui teknologi digital yang digunakan hanya sebatas alat komunikasi seperti handphone. Bukan suatu alasan, karena akses internet yang belum merata menyebabkan masyarakat masih mengalami kendala dalam mengakses internet menggunakan perangkat digitalnya. Alhasil, ini juga berpengaruh terhadap perilaku belanja masyarakat di wilayah perbatasan. Biasanya masyarakat berbelanja di sekitar pos wilayah perbatasan, selain jarak tempuh yang lebih dekat, harga juga lebih murah karena tidak memerlukan biaya tambahan untuk mendapatkan produk/jasa yang diinginkan.

Dengan berkembanganya teknologi digital yang merambah kepada uang digital tentu saja membawa kabar baik bagi masyarakat wilayah perbatasan. Selama ini mereka hanya berbelanja di toko dalam penjualan konservatif lingkup daerahnya atau di border bisa melakukan transaksi yang ditawarkan oleh perusahaan start-up melalui genggaman (handphone). Seperti berbelanja fashion, calon konsumen cukup mempunyai akun di start-up e-marketplace atau $e$ commerce sudah dapat memilih jenis produk yang diinginkan. Setelah memilih produk, konsumen juga dapat langsung bertransaksi melakukan pembayaran dengan fasilitas yang disediakan oleh start-up tersebut. Contoh shopee dengan fasilitas shopeepay, Go-jek dengan fasilitas Go-pay, Lazada dengan fasilitas Laz-pay dan beberapa perusahaan start-up serupa sudah menambahkan fasilitas pembayaran digital untuk memudahkan konsumen dalam melakukan transaksi pembayaran. Selain fasilitas pembayaran digital di start-up, konsumen juga dapat membayar melalui alfamart/indomaret atau bisa juga menggunakan uang digital QRIS. QRIS (Quick Response Code Indonesian Standard) adalah pembayaran uang digital yang diluncurkan oleh Bank Indonesia bekerjasama dengan bank umum lainnya untuk mempermudah masyarakat melakukan transaksi tanpa harus repot membawa uang tunai dalam jumlah besar atau menyiapkan kembalian bagi pemilik usaha ketika bertransaksi.

Kantor Perwakilan Bank Indonesia Provinsi Kalimantan Barat melakukan Sosialisasi dan Edukasi tentang uang digital QRIS serta Kewajiban Penggunaan Uang Rupiah di wilayah NKRI, di aula serta pasar Pos Lintas Batas Negara (PLBN) Entikong, pada 2 Maret 2021 (Kumparan.com, 2021). Hal ini dilakukan dalam rangka mendorong implementasi uang digital di wilayah perbatasan Indonesia.

Gambar 1 berikut ini menyajikan prosentase penggunaan uang digital pada belanja online pada masyarakat wilayah perbatasan Kalimantan Barat.

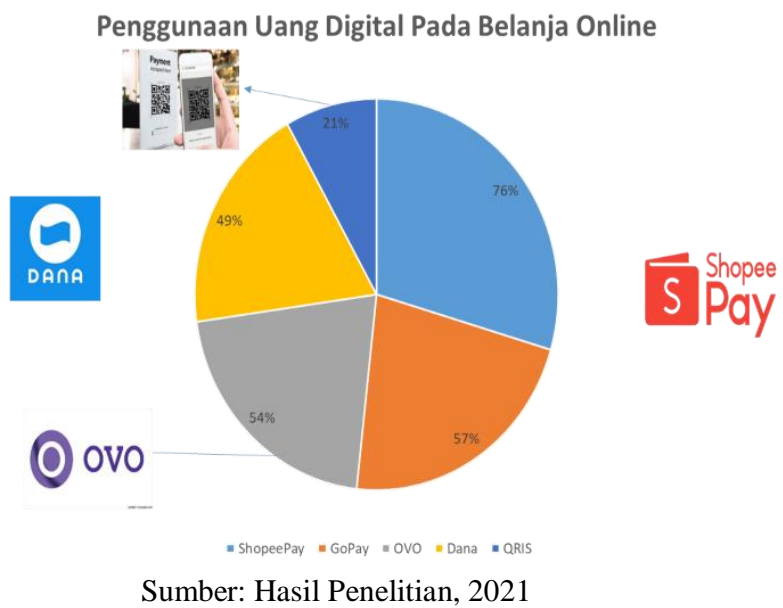

Gambar 1: Penggunaan Uang Digital Pada Belanja Online

Pada gambar 1 diketahui bahwa penggunaan uang digital yang digunakan masyarakat wilayah perbatasan pada belanja online, yaitu terdiri ShopeePay yang paling banyak digunakan (76\%), disusul oleh Gopay (57\%), Ovo (54\%), Dana $49 \%$ dan QRIS 21 $\%$.

Penggunaan uang digital ini berdasarkan banyaknya konsumen pengguna start-up belanja online. Pada gambar 1 diketahui shopeepay paling banyak digunakan yaitu sebesar $76 \%$, ini dikarenakan banyak masyarakat yang berbelanja dengan menggunakan Shopee. Alasan mengapa 
menyukai menggunakan Shopee dibanding emarketplace lainnya adalah karena shopee sering mengadakan promo gratis ongkos kirim, banyak diskon, bisa mengikuti live pada saat toko mengadakan live promo dan mudah menggunakan aplikasinya.

Disusul Go-pay yang penggunaannya berjumlah $57 \%$, masyarakat mengatakan bahwa akan memudahkan jika menggunakan Go-pay ketimbang harus menyiapkan uang tunai saat melakukan transaksi ojek online maupun go-food. Selanjutnya diikuti Ovo sebanyak $54 \%$ karena memudahkan untuk transaksi dan saat transfer untuk kepentingan bisnis. Dan ada masyarakat menggunakan Dana sebanyak $49 \%$ dan QRIS $21 \%$ dalam transaksi berbelanja online maupun offline. Masyarakat/konsumen tidak perlu menyiapkan uang tunai dalam jumlah yang besar untuk bertransaksi, cukup mendekatkan kode QR ke tempat yang disediakan oleh pelaku usaha, transaksi sudah sukses dapat dilakukan. Dan keuntungan bagi pelaku usaha tentunya tidak perlu repot dalam menyiapkan uang kembalian, karena berapa pun jumlahnya tinggal diketik saja nilai nominalnya ke perangkat teknologi digital (handphone, laptop, atau personal computer) transaksi sudah sukses dilakukan.

Penggunaan pembayaran digital ini juga dapat dilakukan pada semua sector usaha, seperti sektor pariwisata, keagamaan (donasi masjid/bencana), kuliner khas daerah, pasar tradisional dan sektor lainnya. Pembayaran dengan menggunakan uang digital sebagai opsi metode pembayaran yang efektif serta membantu menekan penyebaran virus COVID-19 karena tidak perlu menyentuh fisik uang.

Penggunaan uang digital dapat membantu untuk membatasi penggunaan uang tunai atau kertas, tentu saja sangat mempermudah masyarakat dalam melakukan transaksi, karena tidak perlu repot menyiapkan uang tunai untuk transaksi, apalagi kalau nilai nominalnya tidak genap. Badan Kesehatan Dunia (WHO) belum memastikan bahwa uang tunai bisa menjadi vektor penularan Covid-19, tapi setidaknya masyarakat sudah meminimalisir terjadinya kontak fisik saat transaksi (Fatoni dkk., 2020).

Dengan adanya pembayaran digital tentu sangat memudahkan konsumen terutama masyarakat di wilayah perbatasan, karena selama ini masyarakat apabila ingin berbelanja harus mengeluarkan banyak biaya dan waktu tempuh perjalanan yang panjang untuk ke kota. Dengan adanya kemajuan teknologi semakin memberikan kemudahan berbelanja online bagi masyarakat. Di sisi yang lain pemerintah akan sangat terbantukan akan pemerataan perekonomian sampai ke pelosok negeri.

Penggunaan uang digital lebih nyaman dibandingkan penggunaan uang tunai (dalam transaksi bernilai kecil), karena nasabah tidak perlu mempunyai sejumlah uang pas untuk transaksi. Selain itu uang digital juga akan mempengaruhi industri jasa keuangan di masa depan dan mampu mengurangi barrier dalam mengakses industri jasa keuangan. Penggunaan uang digital sebagai alternatif alat pembayaran non-cash menunjukkan adanya potensi yang cukup besar uantuk mengurangi tingkat pertumbuhan penggunaan uang tunai.

Uang digital juga menawarkan transaksi yang lebih cepat dan nyaman dibandingkan dengan uang tunai, khususnya untuk transaksi yang bernilai kecil (micro payment). Keamanan dan kecepatan transaksi ini tentunya menjadi sebuah komoditi yang diperlukan dan cukup efektif untuk terciptanya cash less society, yaitu suatu masyarakat yang minim menggunakan transaksi pembayaran secara cash.Hal ini diindikasi dengan semakin banyaknya pusatpusat perdagangan dan berbagai jenis perusahaan yang menerima pembayaran noncash.

Sistem penggunaan uang digital saat ini pun sudah banyak didukung oleh berbagai macam merchant-merchant atau gerai perbelanjaan. Dengan banyaknya merchant atau gerai perbelanjaan yang telah terintegrasi sistem pembayaran dengan uang digital, maka masyarakat dapat menggunakan uang digital dengan mudah 
untuk melakukan transaksinya. (Tazkiyyaturrohmah, 2018).

\section{KESIMPULAN}

Perkembangan teknologi digital merambah ke semua bidang termasuk bidang keuangan. Transaksi pembayaran yang semula secara tunai bertransisi secara elektronik, atau biasa disebut uang digital atau elektronik. Banyak kemudahan yang didapatkan oleh masyarakat dalam menggunakan uang digital ini, seperti tidak perlu repot membawa uang dalam jumlah besar dan penjual juga tidak repot untuk menyiapkan uang dengan nominal kecil.

Pada era yang serba digital ini bisnis startup di Indonesia juga mempengaruhi transaksi uang digital semakin meningkat. Masyarakat menikmati kemudahan yang diberikan. Tidak perlu ke luar rumah atau pergi ke pasar untuk berbelanja sudah dapat dilakukan di rumah dengan adanya teknologi digital belanja online berbasis start up. Terutama untuk masyarakat di wilayah perbatasan, belanja online yang difasilitasi pembayaran digital sangat membantu dalam bertransaksi. Beberapa bisnis startup yang sedang tren beberapa tahun belakang, seperti Shopee, Go-Jek dan yang lainnya. Perkembangan start up dilengkapi uang digital sebagai pendukung bisnis utama perusahaan. Go-Jek melalui Go-Pay dan Shopee melalui Shopee Pay berinovasi mengembangkan layanan uang digital, karena ini adalah solusi pembayaran sekarang ini dan konsumen cenderung lebih loyal untuk bertransaksi jika memiliki saldo pada uang digital mereka. Dengan menyasar masyarakat mobile, produk uang digital dari dua perusahaan startup ini cukup diminati masyarakat.

\section{DAFTAR PUSTAKA}

Aimon, H., Sentosa, S. U., \& Mahatir, M. R. (2021). E-money and Stock : Empirical Evidence from Indonesia and Thailand. Jurnal Ilmu Ekonomi, 10(1), 139-148. https://doi.org/doi.org/10.15408/sjie.v1 0i1.15380

Bank Indonesia. (2018). Peraturan Bank Indonesia Nomor 20/6/PBI/2018 tentang Perubahan Atas Peraturan Bank Indonesia Nomor 11/12/PBI/2009 Tentang Uang Elekronik (Electronic Money).

https://www.bi.go.id/id/publikasi/peratu ran/Pages/PBI-200618.aspx.

Danuri, M. (2019). Development and Transformation of Digital Technology. Infokam, 15(2), 116-123.

Fatoni, S. N., Susilawati, C., Yulianti, \& Lina, I. (2020). Dampak Covid-19 Terhadap Perilaku Konsumen Dalam Penggunaan E-Wallet Di Indonesia. pp. 1-10.

http://digilib.uinsgd.ac.id/id/eprint/3095 3

Hendarsyah, D. (2016). Penggunaan Uang Elektronik Dan Uang Virtual Sebagai Pengganti Uang Tunai Di Indonesia. Iqthshaduna: Jurnal Ilmiah Ekonomi Kita, 5(1), 1-15. https://doi.org/https://doi.org/10.46367/ iqtishaduna.v5i1.74

Hendarsyah, D. (2019). E-commerce di era industri 4.0 dan society 5.0. IQTISHADUNA: Jurnal Ilmiah Ekonomi Kita, 8(2), 171-184.

Inayah, R. (2020). Pengaruh Persepsi Kemudahan Penggunaan, Persepsi Kemanfaatan dan Promosi Terhadap Minat Penggunaan Uang Elektronik Pada Masyarakat (Studi Kasus di Wilayah Kota Purwokerto). Universitas Islam Negeri Syarif Hidayatullah Jakarta.

Kumparan.com. (2021). Bank Indonesia Kalbar Sosialisasikan QRIS di Perbatasan Malaysia. https://kumparan.com/hipontianak/bank -indonesia-kalbar-sosialisasikan-qrisdi-perbatasan-malaysia-1vJYz2XB7HA

Latif, A., \& Karmilia, R. (2017). Resiko pengelolaan kawasan perbatasan negara dengan model kerja sama ekonomi 
internasional. Jurnal Ilmiah Cano Ekonomos, 6(1), 59-70.

Larina, O.I. \& Akimov, O. M.. (2020). Digital Money at the Present Stage : Key Risks and Development Direction. Digital Financial Assets Original, 24(4), 18-30. https://doi.org/10.26794/2587-56712020-24-4-18-30.

Muazir, S., Lestari, Alhamdani, M.R., \& Nurhamsyah, M. (2020). Menuju Desa Cerdas Perbatasan: Survey Kesiapan Desa Cerdas. Jurnal Pembangunan Wilayah Dan Kota, 16(2), 120-135. https://doi.org/doi.org/10.14710/pwk.v $16 \mathrm{i} 2.27417$

Muralidhar, S. H. (2019). Making Digital Money "Work" for Low-Income Users : Critical Reflections for HCI. International Journal of Mobile Human Computer Interaction (IJMHCI), 11(4), 49-65. https://doi.org/10.4018/IJMHCI.201910 0105

Permana, T., Puspitaningsih, A., Oleo, U. H.,
Tenggara, P. S., Oleo, U. H., \& Tenggara, S. (2019). Fenomena uang digital. Jurnal Ekonomi Pembangunan, 9(2), 363-373.

Peter, M., \& Bican, P. M. (2020). Digital Business Model, Digital Transformation, Digital Entrepreneurship: Is There A Sustainable "Digital"?. Sustainability (Switzerland), 12(5239), 1-16. https://doi.org/10.3390/su12135239

Prasetyo, D. Y. (2016). Peranan Website ECommerce Guna Meningkatkan Perekonomian Di Wilayah Perbatasan (Studi Kasus Pada Umkm Di Kabupaten Indragiri Hilir). Jurnal BAPPEDA, 2(2), $1-8$.

Sugiyono. (2013). Metode Penelitian Pendidikan Pendekatan Kuantitatif, Kualitatif, dan $R \& D$. Bandung: Alfabeta.

Tazkiyyaturrohmah, R. (2018). Eksistensi Uang Elektronik Sebagai Alat Transaki Keuangan Modern. Muslim Heritage, 3(1), 21-39. 